Illinois State University

ISU ReD: Research and eData

Theses and Dissertations

10-13-2014

\title{
Effect of Food Aid Delivery Mode on Food Production in Recipient Nation
}

Steven Marc Wolf

Illinois State University, smwolf@ilstu.edu

Follow this and additional works at: https://ir.library.illinoisstate.edu/etd

Part of the Agricultural and Resource Economics Commons, and the Agricultural Economics Commons

\section{Recommended Citation}

Wolf, Steven Marc, "Effect of Food Aid Delivery Mode on Food Production in Recipient Nation" (2014). Theses and Dissertations. 274.

https://ir.library.illinoisstate.edu/etd/274

This Thesis is brought to you for free and open access by ISU ReD: Research and eData. It has been accepted for inclusion in Theses and Dissertations by an authorized administrator of ISU ReD: Research and eData. For more information, please contact ISUReD@ilstu.edu. 


\section{EFFECT OF FOOD AID DELIVERY MODE \\ ON FOOD PRODUCTION IN \\ RECIPIENT NATION}

Steven M. Wolf

34 Pages

December 2014

The purpose of this study was to provide quantitative evidence linking food aid delivery mode and its correlation with food production in the recipient nation. Debate over the best way to provide food aid to developing countries inspired this study. The three delivery modes used for this study were direct transfer, locally purchase, and triangular purchase. Food aid data was available from The World Food Programme and food production indices were available from The World Bank. Correlations between the independent variable (food aid quantity by delivery mode) and dependent variable (food production index) were examined using the coefficient of determination, which is the Pearson correlation coefficient squared. For direct transfer food aid (aid originating from the donor country), statistically significant negative correlations were found for 17 of the 42 trials. For locally procured food aid (aid originating in recipient country), statistically significant positive correlations were found for 28 of the 42 trials. For triangular purchase (aid originating in a third country), statistically significant negative correlations were found for 8 of the 42 trials, while statistically significant positive correlations were found 
for 6 of the 42 trials. The conclusion of the study was that direct transfer food aid generally has a negative correlation with food production, locally procured food aid has a positive correlation with food production, and triangular purchase has no clear correlation with food production. Locally purchased food aid is recommended as the optimal form of food aid in order to ensure food security. 


\title{
EFFECT OF FOOD AID DELIVERY MODE ON FOOD PRODUCTION IN

\author{
RECIPIENT NATION
}

\author{
STEVEN M. WOLF
}

A Thesis Submitted in Partial Fulfillment of the Requirements for the Degree of

MASTER OF SCIENCE

Department of Agriculture

ILLINOIS STATE UNIVERSITY 
(C) 2014 Steven M. Wolf 


\section{EFFECT OF FOOD AID DELIVERY MODE ON FOOD PRODUCTION IN \\ RECIPIENT NATION}

STEVEN M. WOLF

COMMITTEE MEMBERS:

Dr. Rick C Whitacre, Chair

Dr. Aslihan Spaulding

Dr. Rob Rhykerd 


\section{ACKNOWLEDGMENTS}

I would like to thank Dr. Whitacre, Dr. Spaulding, Dr. Rhykerd, and the rest of the Department of Agriculture at Illinois State University for giving me the chance to complete this Master's program. I was given a shot to prove my abilities despite not having a significant background in this field and I was able to excel with their support and guidance.

I would also like to thank my parents Roz and Dan Wolf for being supportive in everything I have ever done or will decide to do in the future. There have been some difficult times to overcome, but with their belief in me, I have been able to thrive in my studies and in my life as well.

S.M.W. 


\section{CONTENTS}

Page

ACKNOWLEDGMENTS $\quad$ i

$\begin{array}{ll}\text { CONTENTS } & \text { ii }\end{array}$

TABLES iv

FIGURES $\quad$ V

I. INTRODUCTION 1

Introduction of Topic 1

II. REVIEW OF LITERATURE 4

Overview of Types of Food Aid 4

Delivery Modes of Food Aid 6

Criticism of United States Food Aid Policy 8

Effect on Recipient Nation's Markets $\quad 10$

Effect on Donor Nation $\quad 12$

$\begin{array}{ll}\text { About the Participant Countries } & 13\end{array}$

III. METHODOLOGY 16

$\begin{array}{lr}\text { Participants } & 16\end{array}$

$\begin{array}{ll}\text { Variables } & 17\end{array}$

$\begin{array}{ll}\text { Instrumentation and Materials } & 18\end{array}$

$\begin{array}{ll}\text { Hypothesis } & 19\end{array}$

$\begin{array}{ll}\text { IV. RESULTS } & 20\end{array}$

Direct Transfer 20

Locally Procured $\quad 22$

Triangular Purchase $\quad 24$

V. DISCUSSION AND CONCLUSION 26

Analysis of the Data $\quad 26$

Direct Transfer $\quad 26$

Locally Procured 27 
Triangular Purchase

Conclusions

REFERENCES 


\section{TABLES}

Table $\quad$ Page

1. Direct Transfer Correlations 21

2. Locally Procured Correlations 23

3. Triangular Purchase Correlations 25 


\section{FIGURES}

Figure

Page

1. Percent of Total Food Aid from 1990-2008 


\section{CHAPTER I}

\section{INTRODUCTION}

\section{Introduction of Topic}

Approximately one in eight individuals throughout the world (a total of 870 million people) suffers from chronic food insecurity (USAID 2014). Chronic food insecurity is defined as the state of food insecurity that arises and endures as a result of long term not easily changed conditions (USAID 2014). Without assistance from external sources, these people face the negative consequences of hunger and risk the chance of dying from starvation. Populations that have resources to ensure food security for its members often feel a moral obligation to provide assistance to those in need.

While few argue that food aid should be reduced to nothing, debate exists about which forms are most effective. Inefficiencies in the transfer and distribution of food aid lead to wasted time and money. The best method of delivery has not been clearly defined by past research. Delivery modes include direct transfer, local purchase, and triangular purchase. Direct transfer is the delivery of commodities originating from the donor country to the recipient, local purchase is food aid that is purchased in the recipient nation's food surplus areas and transferred to locations with food deficits, and triangular purchase is food aid purchased from a country that is neither the donor nor the recipient (Nugusse 2013). 
The "disincentive effect," which claims that international food aid creates a disincentive for local production has been studied with varying results. Some have found that food aid has led to an increase in food production (Isenman and Singer 1977; Bezunah et al. 2003; Gelan 2007). Others have found no significant effect of food aid on food production (Abdulai et al. 2005). Different studies have found a link between food aid and decreases in production (Motaal 2011; (Sharaunga and Wale 2013).

The intention of this study is to analyze data of delivery modes of food aid and understand their effects on measures of food security. Little empirical evidence exists regarding the effect of delivery mode on food production. Schlossman et al. conducted a study that identified various improvements related to delivery of Public Law 480 Title II food aid from the United States (Schlossman et al. 2011). This study does not look at methods of delivery other than direct transfer. The research team of Christopher B. Barrett has conducted numerous studies related to local and regional procurement (Barrett et al. 2013). Their studies have looked at the cost savings and efficiency improvements of local and regional procurement, analyzed price effects of local and regional procurement on local markets, measured recipient satisfaction with locally and regionally procured food in comparison to food originating from donor countries, analyzed quality and safety of local and regional procured food, and looked at nutritional impacts of local and regional procured food (Barrett et al. 2013). An omission from these studies is the relationship between local and regional procured food and measures of food security.

Analyzing the effects of delivery mode on outcomes in the recipient nations would provide useful insight to government officials and organization leaders responsible for writing laws or allocating funds related to food aid. If a definitive link exists between 
a delivery mode and increased food security and/or poverty reduction, then this information could guide decision makers to the best way of providing food aid. 
CHAPTER II

REVIEW OF LITERATURE

\section{Overview of Types of Food Aid}

Three forms of food aid are program food aid, project food aid (developmental food aid), and emergency food aid (Nugusse 2011). Any aid that requires the procurement of goods and/or services from the donor country is known as "tied aid." Food aid 'in kind' refers to raw or processed agricultural products which are donated to a recipient government or non-governmental organization (Kneteman 2009).

Program food aid originates from crops grown in the donor country and given to the recipient nation so that commodities can be sold on the open market to produce revenue for the recipient nation government (Nugusse 2011). Program food aid can support balance of payments when some of the foreign exchange that would have been spent on food imports is saved and allocated to other budgetary items (Awokuse 2011). Funds gained from the sale of program food aid are often used toward economic development. Because the food aid is sold on the open market, it usually does not end up in the hands of the neediest individuals.

Project food aid targets specific beneficiary groups who participated in activities aimed at triggering economic growth, increasing food security, or other developmental 
programs in the recipient nations (Nugusse 2011). Beneficiary groups include the recipient nation's government, multilateral development agencies, or non-governmental organizations. The World Food Programme is the primary agency responsible for administering multilateral food aid (Awokuse 2011).

Emergency food aid is directed toward recipients who have experienced an unanticipated emergency situation, such as war or a natural disaster (Nugusse 2011). Emergency food aid is not subject to as much controversy as other forms of food aid because it is usually seen as necessary to relieve suffering in the wake of disaster.

The most significant food aid program operated by the United States Government is Public Law 480 (PL-480). PL-480 was signed into law as the Agricultural Trade Development and Assistance Aid of 1954 (Kneteman 2009). Title I of PL-480 (Economic Assistance and Food Security) governs long-term, low-interest loans to developing nations to purchase United States produced food commodities (Kneteman 2009). Title I is administered by the USDA, but currently receives no funding. Title II of PL-480 (Emergency and Private Assistance Programs), also known as "Food for Peace," governs "in-kind" food donations for emergency relief or US commodities to be sold on the open market, known as monetization (Kneteman 2009). In 2009, Title II cost the United States $\$ 2.6$ billion and provided 2.4 million metric tons of commodities. (Food Aid and Security Coalition) Food Aid reform in the 2014 United States budget discontinued the monetization aspect of Title II. (USAID) Funds previously reserved for Title II of PL-480 have been shifted to International Disaster Assistance ( $\$ 1.1$ billion for 2014), The Community Development and Resilience Fund (\$330 million for 2014), and a newly created Emergency Food Assistance Contingency Fund (\$75 million for 2014) (USAID). 
Other food aid programs include Food for Progress, The McGovern-Dole International Food for Education and Child Nutrition Program, and Section 416(b) of the Agricultural Act of 1949. The Food for Progress Program was authorized by the Food for Progress Act of 1985 (USA FSDA). The Food for Progress Act aims to support local agriculture in developing countries by selling donated commodities in the local market and using the proceeds to enhance domestic agricultural infrastructure (USA FSDA). The McGovern-Dole International Food for Education and Child Nutrition Program donates US agricultural products to aid children in low-income nations (USA FSDA). Section 416(b) oversees donations of surplus commodities acquired by the Commodity Credit Corporation (CCC) (USA FSDA). The Commodity Credit Corporation is a government owned entity created to stabilize and support farm incomes (USA FSA). The CCC offers loans to farmers at low rates. Repayments of the loans can be in cash or in the form of commodities; however, most repayments are made in cash.

\section{Delivery Modes of Food Aid}

According to the World Food Programme, the most common delivery mode of food aid, which accounted for $64.4 \%$ of all food aid worldwide in 2012 , is direct transfer (WFP). Direct transfer or direct delivery occurs when commodities are purchased in the donor country and then delivered to the recipient nation (Nugusse 2013). While direct transfer is still the most prevalent delivery mode of food aid worldwide, the percentage of food aid delivered by this method has decreased in the 25 years data has been available from the World Food Programme regarding quantities delivered. In 1988, direct transfer of food aid accounted for $90.6 \%$ of food aid. The percentage of food aid delivered worldwide via direct transfer was as $83.4 \%$ in 2002 , but the percentage of total food aid that was donated through direct transfer steadily declined after 2002. This percentage 
reached a low in 2011, when $50.5 \%$ of worldwide food aid was donated through transfer (WFP). Total food aid provided has generally declined. The peak amount provided was $16,908,492.1$ actual tons in 1993 , while the least provided was 4,690,726.4 actual tons in 2011 (WFP).

Another method of food aid is to provide locally procured commodities rather than commodities originating from the donor country. This is known as local and regional procurement. Locally procuring crops was found to reduce delivery time of commodities by 14 weeks (Lentz et al. 2013). Cost effectiveness of local procurement varied by commodity, but was generally more cost effective for grains, while not always cost effective for processed commodities (Lentz et al. 2013). Local procurement did not have a statistically significant relationship with local price levels or food price volatility (Garg et al. 2013). Risks associated with local and regional procurement include insufficient infrastructure, inadequate local supplies, quality considerations, funding delays, and legal issues (Hanrahan 2009).

Food aid can also be delivered through a triangular purchase, in which the commodities donated are purchased in a country other than the donor or recipient country (Nugusse 2013). This third nation is often another developing nation, boosting the agricultural sector in this country (Shah 2007).

An innovative way to handle food aid is by shifting from donating commodities to cash transfers. Cash transfer provides needy individuals with currency in order to make their own food purchases (Kebede 2006). Large scale cash transfers were found to have an effect on markets, often leading to higher food prices (Kebede 2006). Studies found that a benefit of cash transfers is that recipients of cash were more likely to have diverse 
diets in comparison to recipients of food aid and net household welfare increased for cash recipients (Hidrobo et al. 2012; Gelan 2006).

The European Union has shifted most of its donated food aid to local purchase or triangular purchase, while the United States still predominantly uses direct transfer to provide aid (WFP). In 2012, 93.9\% of food aid donated by the United States was direct transfer, $4.8 \%$ was procured through local purchase, and $1.3 \%$ was procured through triangular purchase (WFP). Figures for the European Community show that only $1 \%$ of food aid was donated through direct transfer, $54.4 \%$ was procured through local purchase, and $44.6 \%$ was procured through triangular purchase. (WFP) These figures do not take cash transfers into consideration.

\section{Criticism of United States Food Aid Policy}

Inefficiencies in traditional United States food aid processes have called into question whether the traditional donation of commodities to developing nations serves as the best method of providing food aid. As of 2009, more than $99 \%$ of all food aid donated by the United States was procured by domestic producers (Kneteman 2009). The original intention of Title I and Title II of Public Law 480 (PL-480), also known as the Agricultural Trade Development and Assistance Act of 1954, was to promote American agricultural interests (Kneteman 2009). In the wake of price supports initiated during the Great Depression, American agricultural producers had significant surpluses which could not be sold on the open market. PL-480 allowed for many of these commodities to be shipped to Europe or developing countries. When there were no longer surpluses the US Government began to purchase commodities through the domestic market, particularly from large agribusinesses (Kneteman 2009). Government food aid contracts were 
awarded on a bid basis to eligible agribusinesses. Through the bid system, the US Government paid up to $70 \%$ more for corn than open market prices and an average of $11 \%$ more for all commodities (Kneteman 2009). A provision in the 1985 Farm Bill requires 75 percent of non-emergency food aid from the US Government to be fortified, bagged or processed (Barrett and Lentz 2009). These activities add significant costs, pricing out small farmers of winning contracts in favor of large agribusiness (Barrett and Lentz 2009). Because of this system of procuring US Commodities, many criticize current policy as a subsidy for large agribusiness.

According to a policy known as Agricultural Cargo Preference (ACP), 75\% of all agricultural aid shipments must be delivered on privately owned, American registered vessels. (Bageant et al. 2010) In order to be eligible under ACP, a vessel must be registered with the United States for at least three years. (Bageant et al. 2010) A 2012 provision in bill number H.R. 4348 reduced the required amount of Government generated cargo (cargo furnished, procured, or financed by the US Government) shipped on American registered vessels to 50\% (Bethel). However, section 318 of the Coast Guard and Maritime Transportation Act of 2014 returned the required amount of Government generated cargo shipped on private US flagged vessels back to 75\% (US AID). About $40 \%$ of these American registered vessels belong to American owned companies that are subsidiaries of foreign companies. (Bageant et al. 2010) The AP Moller-Maersk Group, headquartered in Denmark, owns 21 of the 144 vessels in the US ACP fleet. (Bageant et al. 2010) Contracts are awarded to vessels on a priority bid system that is divided into three priority levels. (Bageant et al. 2010) Priority 1 bids come from shipments that use only US-flagged vessels. If P1 bids are made, they take precedence 
over Priority 2 and Priority 3 bids. (Bageant et al. 2010) Priority 2 bids involve both USflagged and foreign-flagged vessels, while Priority 3 bids involve strictly foreign-flagged vessels. (Bageant et al. 2010) If no Priority 1 bids are made for a given shipment, Priority 2 bidders are chosen based upon price competition. (Bageant et al. 2010) If no Priority 1 or Priority 2 bids are made, then Priority 3 bids are considered. (Bageant et al. 2010) Critics of Agricultural Cargo Preference claim it adds unnecessary costs to the delivery of commodities and serves as a subsidy to a fledgling American shipping industry.

Monetization is the selling of donated food into overseas markets by private voluntary organizations, accounting for sixty percent of American non-emergency food aid in as of 2009. Monetization has been found to be an ineffective and wasteful form of food aid. (Barrett and Lentz 2009) Critics argue monetization interferes with domestic markets by forcing local farmers to sell commodities at low prices or to reduce production. (Motaal 2011) Most monetization is fueled by United States based NonGovernmental Organizations. (Motaal 2011) Food Aid reform in the 2014 United States budget discontinued the monetization aspect of PL-480 Title II. (USAID)

\section{Effect on Recipient Nation's Markets}

Studies analyzing the effect of food aid on local production through "disincentive" effects have been inconclusive. An early study into food aid to India concluded detrimental price effects from food aid were offset by an increase in subsidized food distribution and demand increases stemming from higher incomes (Isenman and Singer 1977). A simulation using a computable general equilibrium modeling technique and using data from Ethiopia found that the removal of food aid would increase food prices and subsequently stimulate food production (Gelan 2007). A 
study analyzing a statistical link between food aid shipments and prices in three markets located in Ethiopia between 1996-2006 found a link between previous year food aid shipments and a reduction of prices in both consumer and producer markets (Tadesse and Shivley 2009). It was found that food aid up to $10 \%$ of domestic production did not produce negative market effects, but food aid more than that would trigger disruption in local markets. Conditioning food aid related to quantities of local market production was recommended as a solution to navigate around disincentive effects (Tadesse and Shivley 2009). A study using household-level data, controlling possible confounding variables, found food aid produces no disincentive effect for production in rural Ethiopia (Abdulai et al. 2005). Another study analyzing the Tunisian economy from 1960-1992 found food aid did not affect domestic production or commercial imports, but rather positive effects gained from the food aid in conjunction with government policies aimed at preventing disincentive effects (Bezunah et al. 2003). Food aid was found to lead to cheaper food prices, creating more buying power for consumers, leading to an increase in food production (Bezunah et al. 2003). A study analyzing food consumption in Northern Uganda found that food aid avoided distress destocking of low value assets for male headed households, meaning households were able to maintain property through lower food expenditures (Hamidu et al. 2013). A study that differentiated between targeted and program (project) food aid, found effects on recipient country food production were statistically significant for program aid, but not for targeted aid (Lowder et al. 2004). Targeted food aid was intended exclusively for free distribution to food insecure individuals. When local markets are influenced through food aid, domestic food security is jeopardized as local production decreases from farmers who cannot compete with low price imports (Motaal 2011). Sharaunga and Wale found food aid, in conjunction with 
price controls, led to a decrease in food production in Malawi (Sharaunga and Wale 2013). A study by Nunn and Qian found that an increase in food aid from the United States leads to an increase in the duration of civil conflict, but no robust effect on intrastate conflicts (Nunn and Qian 2014).

\section{Effect on Donor Nation}

Various theories exist as to why America provides foreign aid. Various types of aid, including food aid, were provided in the wake of World War II to help reconstruction in affected nations. Early theories of donor motives were that the donor nation hoped to gain political favor with the recipient nation, the donor nation hoped to gain long run economic benefit from opening trade with the recipient nation, or for altruistic motives intending to have a favorable impact on needy individuals in the recipient nation (Dudley and Montmarquette 1976). Dudley and Montmarquette found that the likelihood of a donor to give aid to a recipient nation increased as per capita incomes in recipient nations decreased.

The goals for foreign aid as outlined by the United States Agency for International Development were: to create markets for the United States by reducing poverty and increasing production in developing countries, and to diminish the threat of communism by helping countries prosper under capitalism (Bandyopadhyay and Vermann 2013). Colonial relationships and current political alliances were found to be a significant factor in the allocation of foreign aid (Alesina and Dollar 2000). Preference was found to be given to nations within close geographical proximity (Neumayer 2005). Aid originating from the United States was found to be more likely to serve donor interests rather than recipient need in comparison to food aid originating from Europe 
(Neumayer 2005). A relationship between commodity producer interests and aid provided by the United States was also found (Diven 2001). Foreign aid shipments increased when higher government stocks were accumulated (Diven 2001).

An early study on the dispersion of American farm surpluses to developing nations theorizes that the selling of all available commodities on the world market would result in a price lower than actual market price when accounting for donated commodities under PL 480 (Schultz 1960). Schultz estimates the marginal revenue on the open market from the $27 \%$ of commodities donated under PL 480 would have been negative rather than positive (Schultz 1960). Schultz estimates the value of US donated commodities to recipient nations as half the cost of the commodities to the United States, while recipient nations end up paying 10-15 cents on the dollar to obtain these commodities (Schultz 1960). This ratio allows for a net benefit to recipient nations.

\section{About the Participant Countries}

Bangladesh has a population of 156 million people and a GDP of $\$ 130$ billion in 2013 (The World Bank 2014). Improvements in irrigation have allowed for greater crop production, particularly of rice, a staple food (The World Bank 2014). About 47 million Bangladesh citizens remain in poverty (The World Bank 2014). A significant contributor to poverty in Bangladesh is high population density which has put a strain on social services. Infrastructure is underdeveloped and cannot serve the entire population (The World Bank 2014).

Ethiopia has a population of 94 million and a GDP of \$47 billion in 2013 (The World Bank 2014). Per capita income in Ethiopia is $\$ 470$ annually, among the lowest in the entire world (The World Bank 2014). The Ethiopian People's Revolutionary 
Democratic Front has had power in Ethiopia since 1991 and has shifted the country away from highly centralized government into a more democratic system (The World Bank 2014). Malaria and HIV have been significant challenges for the Ethiopian population, as well as poor access to safe drinking water (The World Bank 2014).

Kenya has a population of 44 million and a GDP of $\$ 44$ billion in 2013 (The World Bank 2014). Kenya achieved lower middle income status in 2012, but issues of poverty, low investment, and low productivity continue (The World Bank 2014). Improvements in infrastructure, including electricity and safe water access have improved the standard of living for millions of Kenyans (The World Bank 2014).

Pakistan has a population of 182 million and a GDP of \$237 billion in 2013 (The World Bank 2014). Low spending on health and education (2\% of total GDP) have stunted development (The World Bank 2014). Pakistan's involvement in Middle East conflict, particularly as a base location for the Taliban and other terrorist groups has had a widespread effect on the welfare of its civilian population.

Somalia has a population of 10 million and recent GDP data is not available (The World Bank 2014). Somalia has been fighting an ongoing civil war, which has hampered its ability to respond to natural disasters or other disruptions in the food supply (The World Bank 2014). In 2012, a new government was formed with the election of President Hassan Sheikh (The World Bank 2014). Somalia's politicians and citizens have been unable to reach consensus on a national vision and attempts to establish peace have failed (The World Bank 2014).

Sudan has a population of 38 million and a GDP of $\$ 67$ billion in 2013 (The World Bank 2014). In 2011, the Southern states of Sudan seceded, forming the Republic 
of South Sudan (The World Bank 2014). The secession of South Sudan led to economic shocks, particularly a loss of oil revenue (The World Bank 2014). Rural populations face higher poverty rates than urban populations (The World Bank 2014). Corruption and civil conflict have hindered progress in Sudan.

Yemen has a population of 24 million and a GDP of $\$ 36$ billion in 2013 (The World Bank 2014). Scarce water resources are a major contributing factor to poverty, as Yemen is one of the poorest countries in the Arab world (The World Bank 2014).

Schistosomiasis, a disease stemming from a parasitic worm found in contaminated water, has affected millions of Bangladesh citizens, but efforts to treat infected patients have reduced the magnitude of its devastation (The World Bank 2014). 


\section{CHAPTER III}

\section{METHODOLOGY}

\section{Participants}

Seven countries have been selected for analysis in the study: Ethiopia, Kenya, Sudan, Somalia, Pakistan, Yemen, and Bangladesh. These countries were selected because they are among the largest recipients of food aid, received all three delivery modes of food aid, and represent varying regions of the world (Africa and Asia). Data are available for all of these countries and represents aid donated or food produced throughout the entire country. These seven countries received $24.08 \%$ of all food aid from 1990-2008. Total food aid from 1990-2008 was 189,398,283 actual tons. From 1990-2008 across all nations, $80.28 \%$ of food aid was direct transfer, $6.79 \%$ was locally

procured, and $12.94 \%$ was triangular purchase. 


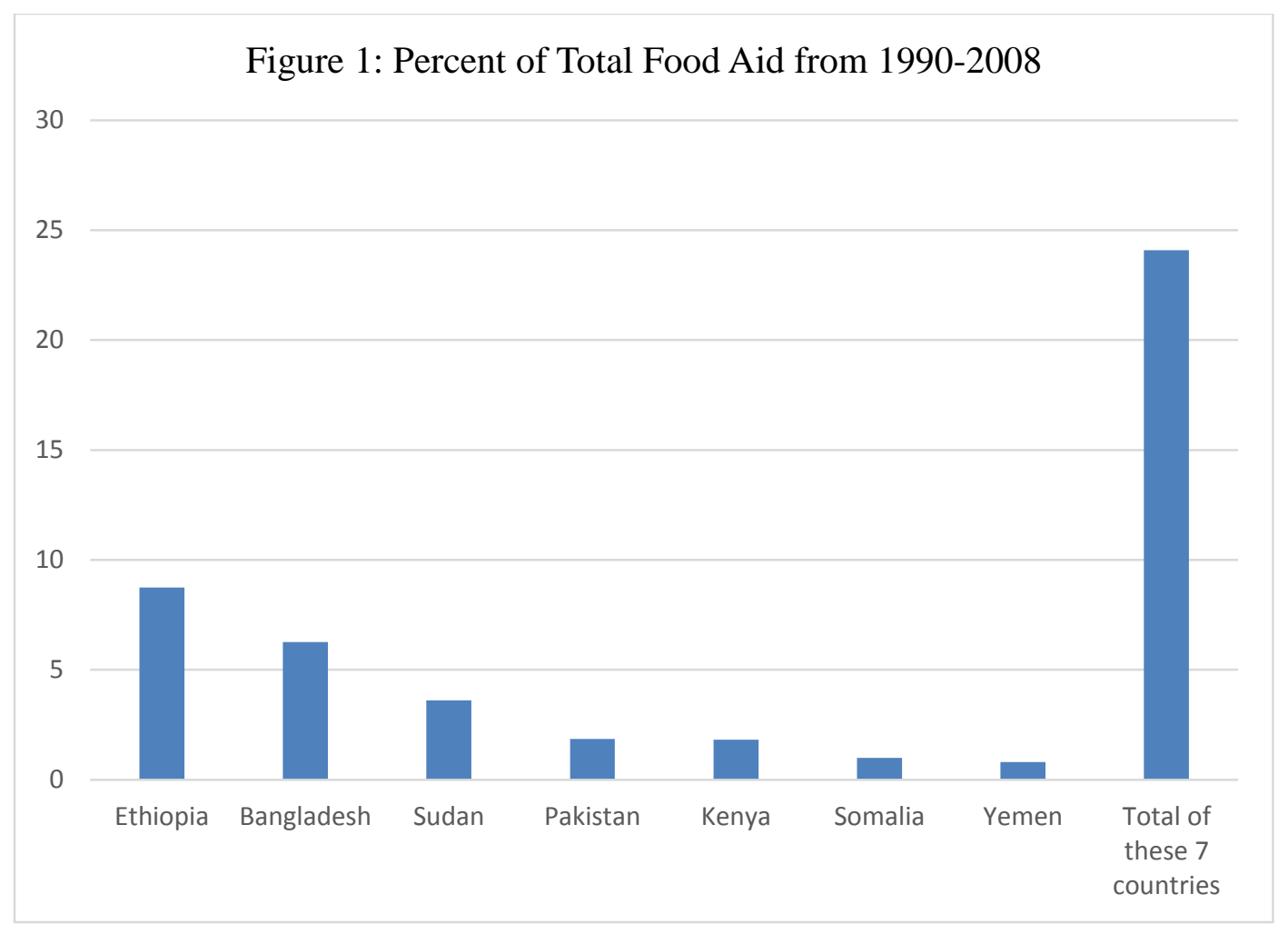

\section{Variables}

The independent variable in the study is delivery mode of food aid. Delivery mode is divided into three categories: direct transfer, local purchase, and triangular purchase. This data are available through The World Food Programme's Food Aid Information System. The data are available from 1988-2012 and is measured in actual tons.

The primary dependent variable is food production, measured through the food production index. Food production index covers food crops that are considered edible and that contain nutrients (The World Bank). Crops used for uses other than consumptions are excluded. Coffee and tea are excluded as well because they contain no nutritional value. The index has a base number of 100 and the base year is the average of production between the years 2004-2006. The index number for each particular year represents a percentage as a comparison to the index from the base years. For example, an index of 70 
in 1999 indicates that food production in 1999 in this country was $70 \%$ of the average food production in the years 2004-2006. This data are available through The World Bank for all seven participating countries from 1993-2012.

\section{Instrumentation and Materials}

Data analysis was conducted using SPSS software from IBM. Pearson coefficients of correlation were used to explore relationships between food delivery modes and the food production index. The Coefficient of Determination or $\mathrm{R}^{\wedge} 2$ was used to evaluate the percentage of variation explained by the independent variable. The coefficient of determination was selected because it is a tool that evaluates explained variance for bivariate models. Various time period lags were used to explore correlations between food aid and the food prediction index. A time lag matches variables that took place in separate years. Because donated food aid will not have an immediate impact on food production, a reactionary period of at least three years is logical in order to explore a meaningful relationship between the variables. Time lags will be used for each number of years between 3 and 8 years after the food aid was donated. For example, for food aid donated in 1995, food production in the years from 1998-2003 will be used as the dependent variable. Time lags were used because the nature of the variables indicates a period of adjustment prior to leading to a meaningful relationship. Each correlation coefficient represents the relationship between the independent and dependent variable over a time period of numerous years. For example, using a three year lag, food aid donated in 1990-2008 was correlated with the food production indices from 1993-2011. An alpha level of .05 was used to indicate a significant correlation, with an alpha level of .01 used to indicate a strong correlation. 
The statistical analysis determined whether increases or decreases in the amount of food aid donated via each delivery mode correlate with increased or decreased food production within the recipient country. The goal was to determine which delivery mode of food aid leads to greater food security within the recipient nation and how long it will take to show a change in food production related to the food aid donated.

\section{Hypothesis}

1. Null: Direct transfer food aid will not show a relevant number of statistically significant correlations with food production.
Alternative: Direct transfer food aid will show a relevant number of statistically significant correlations with food production in the same direction (either negative or positive).

2. Null: Locally procured food aid will not show a relevant number of statistically significant correlations with food production.
Alternative: Locally procured food aid will not show a relevant number of statistically significant correlations with food production in the same direction (either negative or positive).

3. Null: Triangular purchase food aid will not show a relevant number of statistically significant correlations with food production.

Alternative: Locally procured food aid will show a relevant number of statistically significant correlations with food production in the same direction (either negative or positive) 


\section{CHAPTER IV}

RESULTS

\section{Direct Transfer}

The time lags correspond with the following years used in the analysis:

3 Year Lag- 1993-2011 Food Production Index, 1990-2008 Direct Transfer Food Aid Received

4 Year Lag- 1993-2011 Food Production Index, 1989-2007 Direct Transfer Food Aid Received

5 Year Lag- 1993-2011 Food Production Index, 1988-2006 Direct Transfer Food Aid Received

6 Year Lag- 1994-2011 Food Production Index, 1988-2005 Direct Transfer Food Aid Received

7 Year Lag- 1995-2011 Food Production Index, 1988-2004 Direct Transfer Food Aid Received

8 Year Lag- 1996-2011 Food Production Index, 1988-2003 Direct Transfer Food Aid Received

Pearson Correlation Coefficient is listed for each country for each time lag 
Table 1: Direct Transfer Correlations

\begin{tabular}{|c|c|c|c|c|c|c|c|}
\hline & Ethiopia & Kenya & Sudan & Somalia & Bangladesh & Yemen & Pakistan \\
\hline $\begin{array}{c}3 y \\
\text { lag }\end{array}$ & .052 & .100 & -.044 & .154 & $-.696^{* *}$ & -.165 & $-.543^{*}$ \\
\hline $\begin{array}{c}4 y \\
\text { lag }\end{array}$ & .036 & .162 & -.121 & -.110 & $-.695^{* *}$ & -.089 & $-.580^{* *}$ \\
\hline $\begin{array}{c}5 y \\
\text { lag }\end{array}$ & .038 & .154 & -.426 & -.325 & $-.715^{* *}$ & -.026 & $-.589^{* *}$ \\
\hline $\begin{array}{c}6 y \\
\text { lag }\end{array}$ & .027 & .055 & $-.671^{* *}$ & $-.660^{* *}$ & $-.673^{* *}$ & .115 & $-.560^{*}$ \\
\hline $7 \mathrm{y}$ & -.044 & .021 & $-.705^{* * *}$ & $-.623^{* *}$ & $-.614^{* *}$ & .269 & $-.484^{*}$ \\
lag & & & & & & & \\
\hline $\begin{array}{c}8 y \\
\text { lag }\end{array}$ & .078 & -.044 & $-.724^{* *}$ & $-.665^{* *}$ & $-.516^{*}$ & .216 & -.469 \\
\hline
\end{tabular}

* Indicates significance at .05 alpha level

** Indicates significance at .01 alpha level 


\section{Locally Procured}

The time lags correspond with the following years used in the analysis:

3 Year Lag- 1993-2011 Food Production Index, 1990-2008 Locally Purchased Food Aid Received

4 Year Lag- 1993-2011 Food Production Index, 1989-2007 Locally Purchased Food Aid Received

5 Year Lag- 1993-2011 Food Production Index, 1988-2006 Locally Purchased Food Aid Received

6 Year Lag- 1994-2011 Food Production Index, 1988-2005 Locally Purchased Food Aid Received

7 Year Lag- 1995-2011 Food Production Index, 1988-2004 Locally Purchased Food Aid Received

8 Year Lag- 1996-2011 Food Production Index, 1988-2003 Locally Purchased Food Aid Received

Pearson Correlation Coefficient is listed for each country for each time lag. 
Table 2: Locally Procured Correlations

\begin{tabular}{|l|l|l|l|l|l|l|l|}
\hline & Ethiopia & Kenya & Sudan & Somalia & Bangladesh & Yemen & Pakistan \\
\hline $\begin{array}{l}\text { lag } \\
\text { lag }\end{array}$ & $.464^{*}$ & $.747^{* *}$ & .409 & $.663^{* *}$ & $.642^{* *}$ & $.729^{* *}$ & $.667^{* *}$ \\
lag & $.777^{* *}$ & .370 & $.694^{* *}$ & $.578^{* *}$ & $.678^{* *}$ & $.713^{* *}$ \\
\hline $\begin{array}{l}5 y \\
\text { lag }\end{array}$ & $.844^{* *}$ & $.735^{* *}$ & .447 & .346 & .436 & $.614^{* *}$ & $.814^{* *}$ \\
\hline $\begin{array}{l}6 y \\
\text { lag }\end{array}$ & $.872^{* *}$ & $.808^{* *}$ & .351 & -.055 & $.521^{*}$ & $.565^{*}$ & $.795^{* *}$ \\
\hline $\begin{array}{l}7 y \\
\text { lag }\end{array}$ & $.835^{* *}$ & $.777^{* *}$ & .306 & -.162 & $.506^{*}$ & .336 & $.762^{* *}$ \\
\hline $\begin{array}{l}8 y \\
\text { lag }\end{array}$ & $.870^{* *}$ & $.735^{* *}$ & .267 & -.183 & .267 & -.110 & $.696^{* *}$ \\
\hline
\end{tabular}

* Indicates significance at .05 alpha level

** Indicates significance at .01 alpha level 


\section{Triangular Purchase}

The time lags correspond with the following years used in the analysis:

3 Year Lag- 1993-2011 Food Production Index, 1990-2008 Triangular Purchase Food Aid Received

4 Year Lag- 1993-2011 Food Production Index, 1989-2007 Triangular Purchase Food Aid Received

5 Year Lag- 1993-2011 Food Production Index, 1988-2006 Triangular Purchase Food Aid Received

6 Year Lag- 1994-2011 Food Production Index, 1988-2005 Triangular Purchase Food Aid Received

7 Year Lag- 1995-2011 Food Production Index, 1988-2004 Triangular Purchase Food Aid Received

8 Year Lag- 1996-2011 Food Production Index, 1988-2003 Triangular Purchase Food Aid Received

Pearson Correlation Coefficient is listed for each country for each time lag. 
Table 3: Triangular Purchase Correlations

\begin{tabular}{|c|c|c|c|c|c|c|c|}
\hline & Ethiopia & Kenya & Sudan & Somalia & Bangladesh & Yemen & Pakistan \\
\hline $\begin{array}{c}3 \mathrm{y} \\
\text { lag }\end{array}$ & .108 & .041 & .130 & .205 & -.347 & $.596^{* *}$ & -.411 \\
\hline $\begin{array}{c}4 \mathrm{y} \\
\mathrm{lag}\end{array}$ & .063 & .038 & .116 & -.081 & -.446 & $.679^{* *}$ & $-.552^{*}$ \\
\hline $\begin{array}{c}5 \mathrm{y} \\
\mathrm{lag}\end{array}$ & .056 & .264 & -.015 & -.085 & $-.534^{*}$ & $.566^{*}$ & $-.584^{* *}$ \\
\hline $\begin{array}{c}6 \mathrm{y} \\
\mathrm{lag}\end{array}$ & .088 & .210 & $-.516^{*}$ & -.325 & -.445 & $.518^{*}$ & $-.534^{*}$ \\
\hline $\begin{array}{c}7 \mathrm{y} \\
\mathrm{lag}\end{array}$ & .181 & .162 & -.469 & -.435 & $-.500^{*}$ & $.629^{* *}$ & $-.507^{*}$ \\
\hline $\begin{array}{c}8 \mathrm{y} \\
\text { lag }\end{array}$ & .416 & .244 & -.454 & -.454 & -.422 & $.530^{*}$ & $-.530^{*}$ \\
\hline
\end{tabular}

* Indicates significance at .05 alpha level

** Indicates significance at .01 alpha level 


\section{CHAPTER V}

\section{DISCUSSION AND CONCLUSION}

\section{Analysis of the Data \\ Direct Transfer}

For Kenya, Ethiopia, and Yemen, no statistically significant correlations arise when analyzing the correlation between direct transfer food aid and domestic food production using the food production index. For Sudan and Somalia, no statistically significant correlation appears when using a 3, 4, or 5 year lag. However, when using a 6, 7, or 8 year lag, there is a negative correlation significant at the .01 alpha level for both Sudan and Somalia. This indicates that after a period of 6 to 8 years, food production and directly transferred food aid negatively correlate. The lag period may indicate that changes in domestic production take place over a gradual time period as domestic production decisions are not made immediately in response to the amount of directly transferred food aid. Also, agriculture has an inherent time lag from when a production decision is made to the point when the food has been processed into an edible form. For Bangladesh, there is a statistically significant negative correlation for each of the lag periods measured. The negative correlation is significant at the .01 level for a 3, 4, 5, 6, and 7 year lag and at the .05 level for the 8 year lag. For Pakistan, a 4 and 5 year lag 
period indicate a negative correlation significant at the .01 level, and a negative correlation significant at the .05 level for 3,6 , and 7 year lag periods.

Overall, each statistically significant correlation for direct transfer food aid was negative. This indicates that in these particular cases, an increase in directly transferred food aid led to a decrease in recipient country domestic food production after the given lag period or a decrease in directly transferred food aid led to an increase in recipient country domestic food production.

\section{Locally Procured}

For Kenya and Pakistan, each lag period indicates a positive correlation between locally procured food aid and domestic food production significant at the .01 alpha level. Ethiopia has a statistically significant positive correlation at each lag period, with a .05 level significance with a 3 year lag and a .01 level of significance for all other lag periods tested. Somalia has a positive correlation significant at the .01 level with a 3 and 4 year lag, but no statistical significance is evident for any other lag periods. Bangladesh has a positive correlation at the .01 level for a 3 and a 4 year lag, and at the .05 level for a 6 and 7 year lag. There is no significant correlation for the 5 and 8 year lags. Yemen has a positive correlation significant at the .01 level for 3,4 , and 5 year lags, as well as a significant positive correlation at the .05 level for a 6 year lag. No statistical significance is present for a 7 and 8 year lag. Sudan shows no statistically significant link for any of the lag periods tested.

Because all statistically significant correlations for locally procured food aid and food production in the recipient country are positive, this seems to indicate that a 
relationship exists where an increase in locally procured food aid leads to an increase in domestic food production and a decrease in the amount of locally procured food aid leads to a decrease in domestic food production.

\section{Triangular Purchase}

Ethiopia and Kenya showed no statistically significant correlations over any lag period measured between triangular purchased food aid and domestic food production. Sudan's only statistically significant correlation was a negative correlation for a 6 year lag at the .05 alpha level. Bangladesh showed a statistically significant negative correlation at the .05 level for a 5 and 7 year lag period. Pakistan showed a statistically significant negative correlation for a 4, 5, 6, 7, and 8 year lag. The 5 year lag significant at the .01 level, while the other lag periods were significant at the .05 level. In a reversal from trend, all lag periods for Yemen indicated a statistically significant positive correlation. The correlation was significant at the .01 level for 3, 4, and 7 year lags and significant at the .05 level for the 5, 6, and 8 year lags. Because there was no uniform direction of statistical significance and the amount of statistically significant correlations was lower than for the other methods of food aid, there is no distinct conclusion that can be drawn regarding the relationship between triangular purchased food aid and domestic food production in the recipient country of the food aid.

\section{Conclusions}

For part 1 of the hypothesis, regarding direct transfer food aid, the null hypothesis was rejected and the alternative hypothesis was not rejected. There were a relevant number of statistically significant correlations, and they were all in the negative direction. 
For part 2 of the hypothesis, regarding locally procured food aid, the null hypothesis was rejected and the alternative hypothesis was not rejected. There were a relevant number of statistically significant correlations, and they were all in the positive direction. For part 3 of the hypothesis, regarding triangular purchase food aid, the null hypothesis was not rejected and the alternative hypothesis was rejected, as there were not a relevant number of statistically significant correlations. For triangular purchase, the few statistically significant results were in both positive and negative directions.

The results of this study suggest that criticism of direct transfer food aid has validity in regards to its negative consequences for domestic food production in the recipient country. Procuring food aid locally was found to have increased food production, indicating that local procurement is the delivery mode that best ensures food security for the recipient nation. The conclusions of this study can serve as evidence that locally procured food aid has a more desirable effect than direct transfer food aid, and thus future food aid policy should be designed in such a way that local procurement is favored over the direct transfer of commodities. Because the United States is the world's largest food aid donor, particular interest should be given from United States' policy makers regarding the benefits of locally procured food aid. The proverb "Give a man a fish, he eats for a day. Teach a man to fish, he eats for a lifetime" is applicable to direct transfer versus locally procured food aid.

Direct transfer is likely to continue as a method of food delivery; however, much of the benefit from direct transfer food aid is seen in the donor country rather than the recipient nation. Direct transfer food aid may be a necessity during times of emergencies, such as natural disaster or war when locally procured food aid is not a feasible option. 
While direct transfer food aid may have a negative impact on domestic food production, the welfare of individuals in need is critically important. Independent food security for nations is an ideal goal, but the reality is that many nations are far away from having the means to achieve this lofty goal. Direct transfer food aid may be necessary to prevent widespread hunger as local agriculture strengthens its capacity to provide food to its nation's citizens.

In order to support locally procured food aid, investing in agriculture in developing nations is crucial. Providing local farmers with the technology and knowledge necessary to be able to feed their nation's people is a critical aspect in ensuring worldwide food security.

When looking at the various lag periods, the exact length of time that it takes for food aid to impact food production is not apparent. Each lag period had statistically significant results in at least some cases.

A limitation of this study is that it only looked at the relationship between two variables. If other variables, such as project and emergency food aid were used as an additional variable, perhaps the results would tell us more about the relationship between food aid delivery mode and recipient nation food security when the aid is presented as emergency or project aid. Future studies may also look at more countries or take into account the donor country. 


\section{REFERENCES}

Alesina, Alberto, and David Dollar. "Who Gives Foreign Aid To Whom And Why?." Journal Of Economic Growth 5.1 (2000): 33-63. Business Source Complete. Web. 14 Feb. 2014.

Awokuse Titus O.. "Food Aid Impacts on Recipient Developing Countries: A Review Of Empirical Methods And Evidence." Journal Of International Development 23.4 (2011): 493-514. Business Source Complete. Web. 13 Feb. 2014.

Awudu, Abdulai, Barrett Christopher B., and Hoddinott John. "Does Food Aid Really Have Disincentive Effects? New Evidence From Sub-Saharan Africa." World Development 33.(n.d.): 1689-1704. ScienceDirect. Web. 11 Feb. 2014.

Ayele Ulfata, Gelan. "Does Food Aid Have Disincentive Effects On Local Production? A General Equilibrium Perspective On Food Aid In Ethiopia." Food Policy 32.(n.d.): 436-458. ScienceDirect. Web. 13 Feb. 2014.

Bageant, Elizabeth R., Christopher B. Barrett, and Erin C. Lentz. "Food Aid And Agricultural Cargo Preference." Applied Economic Perspectives \& Policy 32.4 (2010): 624-641. Business Source Complete. Web. 13 Feb. 2014.

Bandyopadhyay, Subhayu, Vermann, E. Katarina. "Donor Motives For Foreign Aid." Review (00149187) 95.4 (2013): 327. MasterFILE Premier. Web. 14 Feb. 2014.

Barrett, Chris, and Erin Lentz. "US Monetization Policy: Recommendations for Improvement." Cornell.edu. Chicago Council of Global Affairs, n.d. Web. 14 Feb. 2014.

Bethel, Tom. "The Quick, Quiet Assault on PL-480 U.S.-flag Cargo Preference." American Maritime Officers. American Maritime Officers, n.d. Web. 17 Sept. 2014.

Bezuneh, M., Deaton, B., and Zuhair, S. 2003. "Food Aid Disincentives: the Tunisian Experience." Review of Development Economics 7 (4) (November): 609-621. Web 12 Feb. 2014

"Cargo Preference." U.S. Agency for International Development. US Aid, 10 June 2014. Web. 17 Sept. 20 
"Countries." Countries. The World Bank, n.d. Web. 02 Nov. 2014.

Diven, PJ. "The Domestic Determinants Of US Food Aid Policy." Food Policy 26.5 (n.d.): 455-474. Science Citation Index. Web. 14 Feb. 2014.

Dudley, Leonard, and Claude Montmarquette. "A Model Of The Supply Of Bilateral Foreign Aid." American Economic Review 66.1 (1976): 132. Business Source Complete. Web. 14 Feb. 2014.

"Food Aid." USDA FAS. Food Assistance Division, Web. 16 Feb. 2014.

"Food For Peace." US Food Aid and Security. Food Aid and Security Coalition, n.d. Web. 21 Feb. 2014.

Garg, Teevrat, et al. "Market Prices And Food Aid Local And Regional Procurement And Distribution: A Multi-Country Analysis." World Development 49.(2013): 19-29. Business Source Complete. Web. 14 Feb. 2014.

Gelan, Ayele. "Cash Or Food Aid? A General Equilibrium Analysis For Ethiopia." Development Policy Review 24.5 (2006): 601-624. Academic Search Complete. Web. 14 Feb. 2014.

Hamidu A., Tusiime, Renard Robrecht, and Smets Lodewijk. "Food Aid And Household Food Security In A Conflict Situation: Empirical Evidence From Northern Uganda." Food Policy 43.(n.d.): 14-22. ScienceDirect. Web. 13 Feb. 2014.

Hanrahan, Charles E. "Local And Regional Procurement For U.S. International Emergency Food Aid: R40759." Congressional Research Service: Report (2009): 1. Publisher Provided Full Text Searching File. Web. 14 Feb. 2014.

Hidrobo, Melissa et al. "Cash, Food, Or Vouchers? Evidence From A Randomized Experiment In Northern Ecuador." Journal Of Development Economics 107.(n.d.): 144-156. ScienceDirect. Web. 14 Feb. 2014.

Isenman, Paul J., and H. W. Singer. "Food Aid: Disincentive Effects And Their Policy Implications." Economic Development And Cultural Change 2 (1977): 205. JSTOR Arts \& Sciences VII. Web. 15 Feb. 2014. 
Kebede, Emebet. "Moving From Emergency Food Aid To Predictable Cash Transfers: Recent Experience In Ethiopia." Development Policy Review 24.5 (2006): 579 599. Academic Search Complete. Web. 14 Feb. 2014.

Kneteman, Christie. "Tied Food Aid: Export Subsidy In The Guise Of Charity." Third World Quarterly 30.6 (2009): 1215. MasterFILE Premier. Web. 13 Feb. 2014.

Lentz, Erin C., Simone Passarelli, and Christopher B. Barrett. "The Timeliness And Cost Effectiveness Of The Local And Regional Procurement Of Food Aid." World Development 49.(2013): 9-18. Business Source Complete. Web. 14 Feb. 2014.

Lowder, Sarah K., Douglas Southgate, and Jorge Rodriguez-Meza. "A Post Schultzian View Of Food Aid, Trade And Developing Country Cereal Production: Results of a Vector Autoregression on Panel Data Using Fixed Effects." (2004): AGRIS. Web. 12 Feb. 2014.

Motaal, Doaa Abdel. "Food Aid A MISSED OPPORTUNITY FOR REFORM?." International Trade Forum 3 (2011): 06-07. Business Source Complete. Web. 14 Feb. 2014.

Neumayer, Eric. "Is The Allocation Of Food Aid Free From Donor Interest Bias?." Journal Of Development Studies 41.3 (2005): 394-411. Business Source Complete. Web. 14 Feb. 2014.

Nunn, Nathan, and Nancy Qian. "US Food Aid and Civil Conflict."American Economic Review 104.6 (2014): 1630-666. Business Source Complete. Web. 17 Sept. 2014.

Nugusse, Woldegebrial Zeweld. "Impact Of Food Aid On Household Food Security: Empirical Evidence." African Journal Of Business \& Economic Research 8.1 (2013): 109-125. Business Source Complete. Web. 11 Feb. 2014.

Schlossman, N, et al. "Enhancing Processes For Introduction, Production, Quality Assurance, And Delivery Of US Title II Food Aid Products." Food And Nutrition Bulletin 32.3 (n.d.): S166-S171. Science Citation Index. Web. 19 Feb. 2014.

Schultz, Theodore W. "Value Of U.S. Farm Surpluses To Underdeveloped Countries." Journal Of Farm Economics 5 (1960): 1019. JSTOR Arts \& Sciences VII. Web. 13 Feb. 2014.

Shah, Anup. "Food Aid." - Global Issues. N.p., 7 Dec. 2007. Web. 18 Feb. 2014.

Sharaunga, Stanley, and Edilegnaw Wale. "The Dis-Incentive Effects Of Food Aid And Agricultural Policies On Local Land Allocation In Developing Countries: The Case Of Malawi." Development Southern Africa 30.4/5 (2013): 491-507. Business Source Complete. Web. 25 Feb. 2014. 
Tadesse, Getaw, and Gerald Shively. "Food Aid, Food Prices, And Producer

Disincentives In Ethiopia." American Journal of Agricultural Economics 91.4 (2009): 942-955. EconLit with Full Text. Web. 12 Feb. 2014.

"The Future of Food Assistance: U.S. Food Aid Reform." Usaid.gov. USAID, n.d. Web. 19 Feb. 2014.

"What We Do.” The World Bank, n.d. Web. 13 Apr. 2014.

"World Food Programme Fighting Hunger Worldwide." Food Tracker. World Food Programme, n.d. Web. 18 Feb. 2014 